\title{
KARNOPRAWNA OCHRONA \\ PRZED MOBBINGIEM W PRAWIE POLSKIM \\ - UWAGI DE LEGE LATA I POSTULATY \\ DE LEGE FERENDA
}

WSTĘP

W procesie gospodarowania kapitałem ludzkim istotną rolę ogrywają zasady etyczne, którymi powinien kierować się podmiot, na rzecz którego świadczony jest stosunek pracy. Ważny jest sposób traktowania pracowników przez organizację, który oddziałuje na stosunek pracowników do organizacji. Z etyką zarządzania zasobami ludzkimi powiązany jest mobbing. Działania lub zachowania zdefiniowane jako mobbing wynikają w dużej mierze z nieetycznych zachowań przełożonych, a ich implikacje dostrzec można zarówno w życiu osobistym osoby poddawanej mobbingowi (m.in. osamotnienie, stres) jak również w działaniu organizacji.

Przeciwdziałanie mobbingowi, który stanowi problem w gospodarowaniu kapitałem ludzkim, winno przejawiać się nie tylko poprzez promowanie zasad etycznych w działaniu organizacji oraz wskazywanie korzyści płynących z kształtowania właściwych relacji pomiędzy pracodawcą a pracownikiem, lecz przede wszystkim powinno być oparte o system prawny przewidujący reperkusje dla sprawcy mobbingu zarówno na gruncie prawa prywatnego jak i publicznego. Z uwagi na fakt, że sytuacje, w których pracodawca nie przestrzega praw pracownika, dopuszczając się wobec niego działań lub zachowań zdefiniowanych jako mobbing, nie występują sporadycznie, właściwym wydaje się postawienie zapytania o możliwość pociągnięcia do odpowiedzialności karnej pracodawcy stosującego wobec pracownika mobbing.

Celem niniejszego rozdziału jest zwrócenie uwagi na problematykę odpowiedzialności karnej za działanie lub zachowanie zdefiniowane jako mobbing w świetle

* Doktorant, Katedra Prawa Karnego, Wydział Prawa i Administracji, Uniwersytet Jagielloński. 
aktualnie obowiązujących przepisów prawa polskiego. Istotnym jest udzielenie odpowiedzi na pytanie czy obecny system karnoprawny daje rękojmię efektywnej ochrony przed mobbingiem.

\section{DEFINICJA MOBBINGU}

Mobbing to pojęcie wywodzące się od angielskiego słowa mob, które z kolei oznacza systematyczne i celowe zachowania (szykanowanie, atakowanie, nękanie) naruszające godność osobistą danej osoby ${ }^{1}$. Termin mobbing został po raz pierwszy użyty przez etnografa K. Lorenza do opisania sytuacji osaczania przez zwierzęta najsłabszego osobnika w stadzie. Szwedzki lekarz Paul Heinemann w latach sześćdziesiątych XX wieku posłużył się pojęciem mobbing w odniesieniu do zachowań występujących w grupach społecznych, a tyczyło się ono wrogiego zachowania uczniów wobec siebie w szkołach. W latach osiemdziesiątych XX wieku termin mobbing został wykorzystany w psychologii pracy do scharakteryzowania niektórych destruktywnych zachowań i terroru psychicznego stosowanego wobec pracowników w miejscu pracy².

Z psychologicznego punktu widzenia, mobbing to ekstremalny rodzaj stresu w pracy $^{3}$. Cechuje się on długotrwałością napięcia emocjonalnego z równoczesnym doprowadzeniem do konfliktu na drodze systematycznych działań, których celem jest nękanie pracownika lub grupy osób. Klasyczne ujęcie eksponuje zagadnienie agresji skierowanej wobec jednostki lub grupy osób4.

$\mathrm{Na}$ płaszczyźnie organizacji i zarządzania, mobbingiem w stosunkach pracy można określić wszelkie zachowania w sytuacjach pracy zawodowej wywołujące wśród poszczególnych pracowników lęk, strach i długotrwałe obawy, których skutki ujawniają się nawet uszczerbkiem na zdrowiu ${ }^{5}$.

W znaczeniu prawnym, mobbingiem nazywa się bezprawne, systematyczne i długotrwałe zachowania (działania i zaniechania) osób będących członkami pewnego zespołu ludzkiego, podejmowane bez powodu lub z oczywiście błahego powodu, skierowane przeciwko innym członkom (członkowi) grupy i godzące w ich dobra prawnie chronione, a mające na celu zmuszenie pokrzywdzonego do opuszczenia danego zespołu ${ }^{6}$.

1 S. Kozak, Patologia w środowisku pracy, Difin, Warszawa 2009, s. 171.

2 W. Stelmach, Ciemne strony kierowania, Placet, Warszawa 2005, s. 148.

3 G. Mietzel, Wprowadzenie do psychologii. Podstawowe zagadnienia, GWP, Gdańsk 2003, s. 326 .

4 K. Kmiecik-Baran, W. Cieślak, Bez zgody na przemoc w szkole i pracy, GWP, Gdańsk 2001, s. 24.

5 A. Szałkowski, Problem mobbingu w stosunkach pracy, „Praca i Zabezpieczenie Społeczne” 2002, nr 9, s. 3.

6 K. Kmiecik-Baran, W. Cieślak..., op. cit., s. 115. 
W opinii Międzynarodowej Organizacji Pracy, za mobbing należy uznać „obraźliwe zachowanie przez mściwe, okrutne, złośliwe lub upokarzające usiłowanie zaszkodzenia jednostce lub grupie pracowników (...) którzy stają się przedmiotem psychicznego dręczenia. Mobbing zakłada stałe negatywne uwagi lub krytykowanie, izolowanie osoby od kontaktów społecznych, plotkowanie lub rozpowszechnianie fałszywych informacji?.

\section{DEFINICJA MOBBINGU W PRAWIE POLSKIM}

Definicja legalna mobbingu została umiejscowiona w art. $94^{3} \S 2$ Kodeksu pra$\mathrm{cy}^{8}$, zgodnie z którym, mobbingiem określa się „działania lub zachowania dotyczące pracownika lub skierowane przeciwko pracownikowi, polegające na uporczywym i długotrwałym nękaniu lub zastraszaniu pracownika, wywołujące u niego zaniżoną ocenę przydatności zawodowej, powodujące lub mające na celu poniżenie lub ośmieszenie pracownika, izolowanie go lub wyeliminowanie z zespołu współpracowników".

Powyższa definicja wyłącza możliwość uznania za mobbing jednokrotnego, incydentalnego zachowania9 ${ }^{9}$ Nie jest również możliwe sztywne wskazanie minimalnego okresu niezbędnego do zaistnienia mobbingu. Jak wskazał Sąd Najwyższy, długotrwałość nękania lub zastraszania pracownika w rozumieniu art. $94^{3} \S 2$ k.p. musi być rozpatrywana w sposób zindywidualizowany i uwzględniać okoliczności konkretnego przypadku' ${ }^{10}$.

W piśmiennictwie podkreśla się, iż ustawodawca polski nie wymaga, aby nękanie lub zastraszanie pracownika było działaniem wyjątkowym, odbiegającym znacząco od normalnych zachowań w danym miejscu pracy ${ }^{11}$. Należy jednak zaznaczyć, że nie każde bezprawne działanie pracodawcy wobec pracownika, nawet jeżeli w subiektywnym odczuciu pracownika świadczy o niechęci zwierzchnika wobec niego, może przez sam fakt bezprawności być zakwalifikowane jako mobbing. $Z$ definicji mobbingu wynika bowiem konieczność wykazania nie tylko bezprawności działania, ale także jego celu (poniżenie, ośmieszenie, izolowanie pracownika) i ewentualnych skutków działań pracodawcy (rozstrój zdrowia). Nawet jeżeli działania pracodawcy, skierowane przeciwko prawom pracowniczym, miały charakter powtarzalny, a część z nich została zakwalifikowana jako przestępstwo umyślne popełnione na szkodę pracownika z zamiarem bezpośrednim, kierunkowym, to jednak, bez wykazania

7 M. Zych, Mobbing w polskim prawie pracy, Wydawnictwo C.H. Beck, Warszawa 2007, s. 4.

8 Ustawa z dnia 26 czerwca 1976 roku - Kodeks pracy, Dz.U. z 1998 r., Nr 21, poz. 94 ze zm.

9 D. Dörre-Nowak, Ochrona godności i innych dóbr osobistych pracownika, Wydawnictwo C.H. Beck, Warszawa 2005, s. 254.

10 Wyrok SN z dnia 17 stycznia 2007 roku, I PK 176/06, OSNP 2008, nr 5-6, poz. 58.

11 B. Wagner, Kodeks pracy 2011. Komentarz, Gdańsk 2011, s. 560-561. 
określonego w ustawie celu tego działania, brak jest podstaw do kwalifikowania go jako mobbingu ${ }^{12}$.

Zdaniem Sądu Najwyższego, ocena, czy nastąpiło nękanie i zastraszanie pracownika oraz czy działania te miały na celu doprowadzenie i mogły doprowadzić lub doprowadziły do zaniżonej oceny jego przydatności zawodowej, do jego poniżenia, ośmieszenia, izolacji bądź wyeliminowania z zespołu współpracowników, opierać się musi na obiektywnych kryteriach ${ }^{13}$.

\section{UMIEJSCOWIENIE PRZESTĘPSTW PRZECIWKO PRAWOM OSÓB WYKONUJĄCYCH PRACĘ ZAROBKOWĄ W POLSKIEJ USTAWIE KARNEJ}

Historia polskiego prawa karnego unaocznia rozwój karnoprawnej ochrony osób wykonujących pracę zarobkową. W Kodeksie karnym z 1932 roku14 nie znalazły miejsca przepisy penalizujące czyny skierowane przeciwko dobrom pracowników. Zostały one umiejscowione w Kodeksie karnym z 1969 roku ${ }^{15}$, który przewidywał karalność złośliwego lub uporczywego naruszania praw pracownika wynikających ze stosunku pracy lub z przepisów o ubezpieczeniu społecznym (art. 190), a także narażenia pracownika na bezpośrednie niebezpieczeństwo utraty życia, ciężkiego uszkodzenia ciała lub ciężkiego rozstroju zdrowia wskutek niedopełnienia obowiązków z zakresu bezpieczeństwa i higieny pracy (art. 191).

Obecnie obowiązujący Kodeks Karny ${ }^{16}$ w rozdziale XXVIII zatytułowanym „Przestępstwa przeciwko prawom osób wykonującym pracę zarobkową" wskazuje czyny zabronione skierowane przeciwko pracownikom, które podlegają odpowiedzialności karnej. Mowa o: naruszeniu praw pracowniczych, odmowie przyjęcia do pracy (art. 218), naruszeniu przepisów prawa o ubezpieczeniach społecznych (art. 219), naruszeniu obowiązków BHP (art. 220), niedopełnieniu obowiązków związanych z wypadkiem przy pracy lub chorobą zawodową (art. 221).

Jak podkreśla L. Gardocki, „naruszenie uprawnień pracowniczych jest w zasadzie tylko czynem bezprawnym, powodującym powstanie po jego stronie roszczenia dochodzonego w trybie przewidzianym przez przepisy Kodeksu pracy i Kodeksu postępowania cywilnego. Pewne naruszenia praw pracownika są też penalizowane jako wykroczenia z art. 281-283 k.p. Kodeks karny kryminalizuje jedynie najbardziej jaskrawe postacie takich naruszeń" 17 .

12 Wyrok SN z dnia 5 października 2007 roku, II PK 31/07, OSNP 2008, nr 11-12, poz. 312.

13 Wyrok SN z dnia 14 listopada 2008 roku, II PK 88/08, OSNP 2010, nr 9-10, poz. 114.

14 Rozporządzenie Prezydenta Rzeczypospolitej z dnia 11 lipca 1932 roku - Kodeks karny, Dz.U. Nr 60, poz. 571.

15 Ustawa z dnia 19 kwietnia 1969 roku - Kodeks karny, Dz.U. Nr 13, poz. 94 ze zm.

16 Ustawa z dnia 6 czerwca 1997 roku - Kodeks karny, Dz.U. Nr 88, poz. 553 ze zm.

17 L. Gardocki, Prawo karne, Wydawnictwo C.H. Beck, Warszawa 2010, s. 283. 


\section{ODPOWIEDZIALNOŚĆ KARNA ZA MOBBING}

W polskiej ustawie karnej nie zostało wprost wyodrębnione przestępstwo mobbingu. Na podstawie przepisów części szczególnej Kodeksu karnego można jednak wysnuć konkluzję, że osoba dopuszczająca się wobec pracownika działań lub zachowań zdefiniowanych jako mobbing w wielu przypadkach nie uniknie odpowiedzialności karnej za swoje czyny.

Właściwe jest podkreślenie, iż zachowanie pracodawcy wobec pracownika podejmowane $z$ zamiarem jego nękania czy zastraszania, wypełniać może ustawowe znamiona przestępstw, których głównym przedmiotem ochrony nie są prawa pracownika. Artykuł 207 k.k. przewiduje karalność zachowania sprawcy, który wykorzystując stały bądź przemijający stosunek zależności, znęca się fizycznie lub psychicznie nad pokrzywdzonym. Artykuł 199 § 2 k.k. przewiduje odpowiedzialność karną za czyn popełniony na szkodę małoletniego Ograniczenie człowieka w przysługujących mu prawach ze względu na przynależność wyznaniową lub bezwyznaniowość wyczerpuje ustawowe znamiona przestępstwa z art. 194 k.k. Cześć osoby fizycznej pozostaje pod ochroną art. 212 k.k., penalizującego pomówienie innej osoby o takie postępowanie lub właściwości, które mogą poniżyć ją w opinii publicznej lub narazić na utratę zaufania potrzebnego dla danego stanowiska czy zawodu, a także art. 21 k.k. typizującego znieważenie osoby fizycznej ${ }^{18}$.

Jak słusznie wskazują M. Bosak i A. Danilewicz, ustawowa regulacja mobbingu dla bytu, którego wymagane jest długotrwałe i uporczywe nękanie lub zastraszanie pracownika, przemawia za położeniem nacisku na komparację tego zjawiska z przestępstwem naruszenia praw pracownika, stypizowanym w art. 218 § 1a k.k. ${ }^{19}$ Zgodnie z przepisem tego artykułu, „kto, wykonując czynności w sprawach z zakresu prawa pracy i ubezpieczeń społecznych, złośliwie lub uporczywie narusza prawa pracownika wynikające ze stosunku pracy lub ubezpieczenia społecznego, podlega grzywnie, karze ograniczenia wolności albo pozbawienia wolności do lat 2".

Przedmiotem ochrony czynu zabronionego z art. 218 § la k.k. są prawa osób wykonujących pracę zarobkową. Przepis chroni prawa przysługujące osobie świadczącej pracę w trakcie zatrudnienia oraz po jego ustaniu, ale nie chroni praw osób, co do których stosunek zatrudnienia jeszcze nie powstał20.

W opinii W. Wróbla, przepis art. 218 § 1a k.k. chroni również osoby, które faktycznie są pracownikami, choć wykonują pracę na podstawie umowy cywilnoprawnej, na przykład zlecenia ${ }^{21}$. Z tożsamej ochrony nie będą mogli skorzystać funkcjonariusze

18 M. Bosak, A. Danilewicz, Odpowiedzialność cywilna i karna za mobbing, „Prokuratura i Prawo" 2010, nr 4, s. 109-110.

19 Ibidem, s. 110.

20 M. Mozgawa (red.), Kodeks karny. Komentarz, LEX nr 8591.

21 A. Zoll (red.), Kodeks karny - cześć szczególna. Komentarz, t. 2, Kraków 2006, s. 861. 
służb mundurowych, gdyż służba w formacjach zmilitaryzowanych (wojsku, Policji, Straży Granicznej etc.) podlega wyłączeniu z pojęcia stosunku pracy, z uwagi na dyspozycyjność funkcjonariuszy ${ }^{22}$.

Złośliwe lub uporczywe naruszanie praw pracownika to przestępstwo, które można popełnić i przez działanie i przez zaniechanie. Występek z art. 218 § 1a k.k. ma charakter formalny. Do jego dokonania nie jest potrzebny skutek w postaci doznania przez pracownika pokrzywdzenia poprzez naruszenie jego praw ${ }^{23}$.

Aby można było mówić o wypełnieniu znamion czynu zabronionego zdefiniowanego w art. 218 § 1a k.k. musi wystąpić „złośliwość” lub „uporczywość” naruszania praw pracownika. Przez „złośliwość” rozumie się nie tylko zachowanie umyślne, ale także nakierowane na cel w postaci chęci wyrządzenia innej osobie krzywdy, dolegliwości. Niezbędne jest tu ustalenie, że naruszanie praw określonego pracownika nie ma żadnych racjonalnych przyczyn, motywowane jest jedynie personalną niechęcią do jego osoby²4. „Uporczywość” oznacza, że zachowanie sprawcy albo ma trwać przez pewien czas, albo powtarzać się kilkakrotnie, musi zawierać również świadomość niweczenia tym możliwości osiągnięcia stanu założonego przez prawo ${ }^{25}$.

Przestępstwo określone w art. 218 § 1ak.k. jest indywidualne co do czynu. Czyn określony w § la może popełnić jedynie osoba, która wykonuje czynności w sprawach z zakresu prawa pracy i ubezpieczeń społecznych, bez względu na to, czy jest odpowiedzialna za sprawy związane z zatrudnieniem, a zatem zarówno pracodawca lub osoba przezeń wyznaczona, jak i na przykład urzędnik Powiatowego Urzędu Pracy lub sekretarka sądowa w sądzie pracy, dyrektor, kierownik, prezes zarządu spółdzielni lub spółki, a nawet szeregowy pracownik, na przykład działu kadr, który w imieniu pracodawcy wykonuje czynności w sprawach z zakresu prawa pracy i ubezpieczeń społecznych ${ }^{26}$.

Czy zabroniony z art. 218 § 1a k.k. możne zostać popełniony jedynie umyślnie. W zależności od postaci czynności sprawczej popełnić je można tylko w zamiarze bezpośrednim („złośliwie”) oraz zarówno w zamiarze bezpośrednim, jak i ewentualnym („uporczywie”)

Analiza ustawowej definicji mobbingu pozwala na konstatację, iż zawarte w niej zachowania można odnieść do ustawowych znamion występku z art. 218 § 1ak.k. Trzeba jednak zauważyć, że nie każde zachowanie naruszające art. 94³ k.p. stanowić będzie o realizacji ustawowych znamion tego przestępstwa. W doktrynie podkreśla się, iż tylko część przypadków stosowania mobbingu będzie odpowiadać dyspozycji

22 K.W. Baran, Prawo pracy, Kraków 2008, s. 32-33.

23 M. Mozgawa, op. cit., LEX nr 8591.

24 W. Wróbel, op. cit., s. 869.

25 Postanowienie SA w Krakowie z dnia 13 grudnia 2000 r., II AKz 289/00, KZS 2000, z. 12, poz. 28.

26 M. Mozgawa, LEX nr 8591.

27 Ibidem. 
przepisu art. 218 § 1ak.k. Nie jest zatem możliwe stosowanie tego przepisu automatycznie do każdego przypadku mobbingu²8.

Ponadto, należy wskazać, że w szczególnych przypadkach, kiedy efektem bezprawnego zachowania pracodawcy bądź współpracownika będzie sprowadzenie zagrożenia dla życia lub zdrowia pokrzywdzonego, mobbing wyczerpywać będzie także znamiona czynu zabronionego z art. 220 k.k. (penalizującego niedopełnienie obowiązków z zakresu BHP) ${ }^{29}$.

\section{UWAGI KOŃCOWE}

Mobbing stanowi problem ważki społecznie. Działania lub zachowania zdefiniowane jako mobbing wywołują szereg negatywnych następstw. Warto chociażby zaznaczyć, że ze względu na trwałość zachowania względem ofiary i reakcyjny dynamizm zdolności do bycia skrzywdzonym osoby pokrzywdzone są ze względu na poniesione szkody psychiczne na długi czas lub nawet trwale usunięte z rynku pracy ${ }^{30}$.

Warunkiem sine qua non ograniczenia występowania zjawiska mobbingu w środowisku pracy jest funkcjonowanie efektywnego systemu prawnego przewidującego reperkusje dla sprawcy mobbingu zarówno na gruncie prawa prywatnego jak i publicznego. Obecnie obowiązująca w Polsce ustawa karna znajduje, co prawda, zastosowanie do części przypadków stosowania mobbingu, jednak nadal odnaleźć można bezprawne zachowania mobbera, którym nie można przypisać sankcji karnej. Właściwym wydaje się więc postawienie zapytania o możliwość i celowość bezpośredniej kryminalizacji mobbingu.

$\mathrm{Na}$ temat potrzeby kryminalizacji działań lub zachowań zdefiniowanych jako mobbing w 2011 roku wypowiedziała się Komisja Kodyfikacyjna Prawa Karnego, która w swojej opinii31 zajmuje stanowisko przeciwko bezpośredniej kryminalizacji zachowań mobbingu w rozdziale XXIII k.k. Komisja zwróciła uwagę na fakt braku szczegółowych danych z badań kryminologicznych (wiktymizacyjnych) dotyczących mobbingu, co uniemożliwia ocenę skali zjawiska. Ponadto wskazała, że bezpośrednia kryminalizacja mobbingu mogłaby w praktyce być traktowana jako lex specialis wobec regulacji pozwalających na pociągnięcie do odpowiedzialności karnej za inne typy czynów zabronionych (stanowiących postać mobbingu) i skutkować obniżeniem poziomu ochrony karnoprawnej ofiar szczególnie drastycznym przypadkom mobbingu.

28 W. Cieślak, Z karnoprawnej problematyki mobbingu, [w:] Ł. Pohl (red.), Aktualny problemy prawa karnego. Księga pamiątkowa z okazji jubileuszu 70. urodzin Profesora Andrzeja J. Szwarca, Poznań 2009, s. 77.

29 J. Unterschütz, Karnoprawna ochrona praw osób wykonujących pracę zarobkową, Wolters Kluwer SA, Warszawa 2010, s. 139.

30 W. Cieślak, J. Stelina, Mobbing (prześladowanie) - próba definicji i wybrane zagadnienia prawne, „Palestra” 2003, nr 9-10, s. 72.

31 bip.ms.gov.pl [dostęp: 10.11.2014 r.]. 
Stanowisko prezentowane przez Komisję Kodyfikacyjną Prawa Karnego wydaje się słuszne. Trudno bowiem nadać racjonalność uzupełnieniu części szczególnej polskiej ustawy karnej o typ czynu zabronionego przenoszącego w definicję mobbingu. Pojęcie mobbingu nie nosi bowiem znamion klarownego. Wobec tego, pełne opisanie znamion takiego przestępstwo wydaje się mało realne.

Nie zmienia to jednak faktu, że za zasadne należy uznać ciągłe monitorowanie skali zjawiska mobbingu oraz analizowanie sposobu naruszania dyspozycji art. 94 § 2 k.p. Czynności te umożliwią ustawodawcy szybką reakcję na większą liczbę przypadków mobbingu poprzez pociągnięcie sprawcy do odpowiedzialności karnej za inne typy czynów zabronionych (ustawowe znamiona, których wypełni zachowanie pracodawcy wobec pracownika), a także wprowadzenie ewentualnych nowelizacji, które zminimalizują występowanie sytuacji bezkarności mobbera.

\section{BIBLIOGRAFIA}

Baran K.W., Prawo pracy, Kraków 2008.

Bosak M., Danilewicz A., Odpowiedzialność cywilna i karna za mobbing, „Prokuratura i Prawo” 2010, nr 4.

Cieślak W., Bez zgody na przemoc - w szkole i pracy, Gdańsk 2001.

Cieślak W., Stelina J., Mobbing (prześladowanie) - próba definicji i wybrane zagadnienia prawne, „Palestra” 2003, nr 9-10.

Dörre-Nowak D., Ochrona godności i innych dóbr osobistych pracownika, Warszawa 2005.

Gardocki L., Prawo karne, Warszawa 2010.

Kozak S., Patologia w środowisku pracy, Difin, Warszawa 2009.

Mietzel G., Wprowadzenie do psychologii. Podstawowe zagadnienia, Gdańsk 2003.

Mozgawa M. (red.), Kodeks karny. Komentarz, LEX nr 8591.

Pohl Ł. (red.), Aktualny problemy prawa karnego. Księga pamiątkowa z okazji jubileuszu 70. urodzin Profesora Andrzeja J. Szwarca, Poznań 2009.

Stelmach W., Ciemne strony kierowania, Warszawa 2005.

Szałkowski A., Problem mobbingu w stosunkach pracy, "Praca i Zabezpieczenie Społeczne” 2002, nr 9.

Unterschütz J., Karnoprawna ochrona praw osób wykonujących pracę zarobkową, Wolters Kluwer SA, Warszawa 2010.

Wagner B. (red.), Kodeks pracy 2011. Komentarz, Gdańsk 2011.

Zoll A. (red.), Kodeks karny - cześć szczególna. Komentarz, t. 2, Kraków 2006.

Zych M., Mobbing w polskim prawie pracy, Warszawa 2007.

\section{Źródła internetowe}

www.bip. ms.gov.pl

\section{Akty prawne}

Ustawa z dnia 19 kwietnia 1969 roku Kodeks karny, Dz.U. Nr 13, poz. 94 ze zm.

Ustawa z dnia 26 czerwca 1976 roku Kodeks pracy, Dz.U. z 1998 r., Nr 21, poz. 94 ze zm.

Ustawa z dnia 6 czerwca 1997 roku Kodeks karny, Dz.U. Nr 88, poz. 553 ze zm.

Rozporządzenie Prezydenta Rzeczypospolitej z dnia 11 lipca 1932 roku - Kodeks karny, Dz.U. Nr 60, poz. 571. 